\title{
Os dissabores amordaçados da velhice em Lygia Fagundes Telles e Clarice Lispector
}

\author{
Old age's muzzled sorrows in \\ Lygia Fagundes Telles and Clarice Lispector \\ Los disgustos amordazados de la vejez en \\ Lygia Fagundes Telles y Clarice Lispector \\ Yls Rabelo Câmara* \\ Yzy Maria Rabelo Câmara*
}

\section{Resumo}

Esse artigo objetiva mostrar o conceito de velhice feminina no Brasil dos anos 1970 a partir da análise de "Senhor Diretor" e "A partida de trem", dois contos escritos respectivamente por Lygia Fagundes Telles (1977) e Clarice Lispector (1974). Para tanto, fizemos um levantamento bibliográfico e, baseando-nos em investigadores como Ferreira (2014) e Beauvoir (1990), entre outros, analisamos psicológica e literariamente as personagens Maria Emília e Maria Rita, as protagonistas dos contos supracitados. Ao colocá-las em paralelo, verificamos o quanto o envelhecer da mulher pode ser marcado por modos de subjetivação negativos que causam sofrimento por rejeição, baixa autoestima, solidão, introjeção de prénoções distorcidas, negação da sexualidade e desesperança e que, apesar dos contos em questão reforçarem esses padrões sócio-historicamente construídos, essa pesquisa tem como relevância também mostrar a velhice sob um prisma de plenitude e de busca de sentido de vida.

Palavras-chave: velhice, literatura brasileira, modos de subjetivação.

\begin{abstract}
This article aims to show the concept of old age in Brazil of the seventies through the analysis of "Senhor Diretor" and "A partida do trem", two short stories written by Lygia Fagundes Telles (1977) and Clarice Lispector (1974), respectively. To do so, we did a bibliographical survey and, based on theorists such as Ferreira (2014) and Beauvoir (1990), among others, we analyzed psychologically and literarily the characters Maria Emília and Maria Rita, the protagonists of the short stories mentioned above. By placing them alongside each other, we see how aging can be marked by negative modes of subjectivation that cause suffering due to rejection, low selfesteem, loneliness, the introjection of preconceived notions, denial of sexuality, and hopelessness. And while the short stories reinforce these socio-historically constructed standards, this research is also relevant in showing old age under a prism of fullness and a search for meaning in life.
\end{abstract}

\begin{abstract}
Resumen
Este artículo tiene como objetivo mostrar el concepto de vejez femenina en Brasil de los años 1970 a partir del análisis del "Senhor Diretor" y "A partida do trem", dos cuentos escritos respectivamente por Lygia Fagundes Telles (1977) y Clarice Lispector (1974). Para ello, hicimos un levantamiento bibliográfico $y$, basándonos en investigadores como Ferreira (2014) y Beauvoir (1990), por citar algunos, analizamos psicológica y literariamente a los personajes María Emilia y Maria Rita, las protagonistas de los cuentos anteriormente mencionados. Al ponerlas en paralelo, verificamos cuanto el envejecer de la mujer puede ser marcado por modos de subjetivación negativos que causan sufrimiento por rechazo, baja autoestima, soledad, introyección de nociones distorsionadas, negación de la sexualidad y desesperanza y que, a pesar de que los cuentos en cuestión refuercen estos patrones socio-históricamente construidos, esta investigación tiene como relevancia también
\end{abstract}

\footnotetext{
* Doutora em tendências atuais nos estudos ingleses e suas aplicações e pós-doutoranda em educação na Universidade Estadual do Ceará, Fortaleza, CE, Brasil. (Dorcid.org/0000-0002-2009-5022. E-mail: ylscamara@ hotmail.com

** Doutoranda em psicologia social na Universidad Argentina John F Kannedy, Buenos Aires. (Dorcid.org/0000-0003-3415-1838. E-mail: yzycamara@gmail.com
} 
Keywords: old age, Brazilian literature, modes of subjectivation. mostrar la vejez bajo un prisma de plenitud y de búsqueda de sentido de vida.

Palabras clave: vejez, literatura brasilera, modos de subjetivación.

\section{Considerações iniciais}

Este número da revista Estudos de Literatura Brasileira Contemporânea traz, como dossiê, a romancista e contista Lygia Fagundes Telles - a primeira-dama de nossa literatura. Prestes a completar seu centenário daqui a cinco anos, Telles teve sua trajetória plasmada no documentário Lygia, uma escritora brasileira, em 2017. Amplamente aclamada por seu público leitor e por críticos literários dentro e fora do país, sua importância pode ser mensurada por seu lastro literário: quatro romances; vinte livros de contos; participações em antologias e coletâneas; adaptações de sua obra para o cinema, para o teatro e para a televisão, além da tradução de suas principais obras para vários idiomas (alemão, inglês, espanhol, francês, italiano, sueco, polaco e tcheco).

Neste artigo analisamos como ela e Clarice Lispector (jornalista e escritora contemporânea sua, igualmente aclamada pela crítica e pelo público antes e depois de sua morte prematura, em 1977) descrevem a velhice feminina em dois de seus contos, respectivamente "Senhor Diretor" (1977) e "A partida do trem" (1974). Destarte, primeiramente apresentamos como ambas as autoras tratam suas personagens femininas idosas (ponto fulcral de ambos os contos e desse artigo, por extensão) para, em seguida, analisamos as duas personagens em questão nos contos supracitados.

Faz-se necessário esclarecer que tanto Telles como Lispector, alguns dos investigadores aqui mencionados e nós, autoras, utilizamos as palavras "velho" e "velha" destituídas de eufemismo mas também de qualquer alusão à ofensa. Esses vocábulos são repetidamente empregados ao longo desse trabalho com a mesma carga semântica conferida por Beauvoir (1990) em sua obra basilar A velhice.

Passemos, então, à análise das agruras da velhice feminina no Brasil dos anos 1970, ponto de partida para a recensão das personagens que nos propusemos a estudar neste artigo.

\section{Personagens femininas idosas sob a ótica de Lygia Fagundes Telles e Clarice Lispector}

As protagonistas de Telles representam a mulher inserida no contexto social atual e, ao destacar as velhas em sua obra, ela amplia a discussão em torno da mulher no sentido de buscar para ela um lugar na sociedade que contemple sua dignidade, suas limitações e sua sexualidade. Entre suas inesquecíveis personagens femininas idosas, escolhemos uma, de seus contos, para analisarmos o tema da velhice e suas implicações: Maria Emília, de "Senhor Diretor" (1977).

Por sua vez, Clarice Lispector, que surgiu no cenário literário brasileiro nos anos 1940 em meio ao assombro da crítica e à acolhida do público, tal como Telles, estudou direito, mas nunca exerceu a profissão: sua vocação também estava na literatura. $O$ interesse de Lispector pelo universo feminino pode ser notado em seus contos e romances, com protagonistas inquietas e de difícil relacionamento com o elemento masculino, sempre às voltas com temas como amor, maternidade e velhice (Figueiredo, 2011). O existencialismo é uma marca distintiva do estilo clariceano no design das personagens femininas no que tange a questões subjetivas. Elas são, invariavelmente, esposas, donas de casa, solteironas e/ou idosas. Independentemente da idade, todas têm seus dramas relacionados com as dores de se viver em uma sociedade machista, preconceituosa e excludente (Prazeres, 2015).

Especificamente no conto "A partida do trem", como defende Figueiredo (2011), está implícita a questão do desejo advinda da carência que a solidão proporciona, mas diferentemente de Maria Emília, a velha protagonista em "Senhor Diretor", que tem suas carências afetivas intimamente ligadas à nulidade de sua vida sexual, Maria Rita, a velha protagonista de "A partida do trem", sofre com o amor que sua família lhe negligencia. 
Normalmente, a velha, para Lispector, recebe um tratamento especial, principalmente nos contos, onde a autora aborda a velhice de forma real e natural, expondo as limitações próprias dessa etapa da vida, como a solidão e a pouca atenção dispensada pelas famílias às suas velhas, abandonando-as, muitas vezes, ou prescindindo de suas necessidades. Nos contos clariceanos existe uma tendência natural das personagens idosas, perdidas em suas trajetórias, de guardarem uma intimidade reservada, quase sagrada, que se alia ao grotesco da situação de abandono social em que se encontram.

Para exemplificarmos o que aqui expomos, analisamos a seguir "Senhor Diretor", de Lygia Fagundes Telles, e "A partida do trem", de Clarice Lispector, que abordam o tema da velhice feminina incompreendida, mais especificamente o ocaso de Maria Emília e de Maria Rita, as protagonistas de ambos os contos respectivamente.

\section{Sobre Maria Emília em "Senhor Diretor"}

Esse conto foi publicado no livro Seminário dos ratos em 1977, época em que a ditadura militar amordaçava a sociedade brasileira, fundamentalmente patriarcal e cristã, que se chocava com algumas liberdades carnais jamais demonstradas na mídia antes, sociedade essa que se flexibilizava perante os avanços de uma nova concepção de liberdade, de amor livre e de sexualidade:

Segundo informa Constância Lima Duarte (2003), nessa época, o movimento feminista debatia sobre sexualidade, virgindade e reivindicava o direito ao aborto e ao prazer feminino. A pílula anticoncepcional, que havia surgido na década anterior, permitiu à mulher um maior controle sobre seu corpo, favorecendo a desvinculação entre sexo e reprodução. O comportamento sexual dos brasileiros começava a mudar. Entretanto, os adultos dessa época eram fruto de uma educação extremamente repressora, havendo um conflito entre os valores tradicionais que ainda vigoravam e os novos padrões morais que começavam a surgir (Ferreira, 2014, p. 52).

Dois anos antes, havia-se instituído o ano de 1975 como o Ano Internacional da Mulher, fato que favoreceu uma maior abertura para o diálogo entre feministas e sociedade. Telles participava de reuniões que discutiam temas pertinentes a essa nova maneira de repensar o elemento feminino e essa influência é clara em sua obra na época (Ferreira, 2014).

A protagonista do conto "Senhor Diretor" é Maria Emília, uma professora paulista aposentada de sessenta e dois anos, virgem, ressentida com a liberdade sexual da juventude dos anos 1970 e com a liberdade sexual de algumas de suas poucas amigas na mesma faixa etária que a dela. O fato de ser professora, na sua idade, representa um detalhe pejorativo que Telles plasma de forma sensível em seu conto:

O adjetivo "solteirona" tinha, e ainda tem, uma conotação negativa, pois representa não apenas a mulher que não é casada, mas que também é virgem, ou seja, aquela que não cumpriu seu destino "natural" de mulher. A professora solteirona era representada, geralmente, por uma figura severa, sem atrativos físicos e com o semblante fechado, sem demonstrações de sentimentos. Em "Senhor Diretor", Maria Emília é caracterizada como uma professora solteirona, virgem aos sessenta e dois anos, solitária e com um modo severo de se vestir e se comportar. Percebe-se que Lygia Fagundes Telles constrói uma personagem verossímil, condizente com uma perspectiva histórica. Ao criar uma personagem próxima da realidade, Telles chama a atenção para a condição da mulher, reprimida no campo pessoal e também profissional (Ferreira, 2014, p. 59).

O enredo desse conto inicia-se, pois, com Maria Emília indignada, em frente a uma banca de revistas, tendo diante de si capas de revistas estampadas com mulheres seminuas e molhadas, com suas curvas destacadas entre as manchetes de jornais que procura ler. Incomodada, resolve escrever uma carta ao diretor de um jornal para expor sua indignação perante a onda de imoralidades que estava sendo obrigada a testemunhar nos últimos anos na grande mídia. A carta vai sendo escrita mentalmente, em primeira pessoa, ao passo que a personagem caminha pelas ruas de São Paulo. Era seu aniversário e estava sozinha. As críticas e reclamações que pretendia materializar em forma de carta mostram a amargura de 
uma mulher que envelhecera solitária. É então quando entra em um cinema e ali o foco narrativo passa a ser em terceira pessoa, através de um narrador onisciente, com o fluxo de consciência de Maria Emília entrecortando seu discurso e mesclando ao que quer reclamar ao diretor, demandas suas, especialmente da velhice que já lhe chegara:

Já estava escrevendo uma outra carta, meus Céus, não misturar os assuntos que velhice era outro tópico, agora tinha que se concentrar nessa sufocante onda de vulgaridade que contaminava até as pedras. A poluição também ficaria para uma outra vez, o que interessava denunciar era essa poluição da alma (Telles, 1998, p. 17).

Percebemos, então, que essa carta é, na verdade, uma catarse à guisa de diário, um "monólogo ressentido" como o define Pedra (2010). Sem ter com quem conversar, uma vez que suas amigas ou já estão mortas ou se comportam de forma diferente da sua, regendo-se levemente pelos logros que a liberdade sexual trouxe e que ela condena, a protagonista estende suas angústias para além da crítica ao comportamento vergonhoso de algumas mulheres de seu entorno e arrasta sua angústia para o âmbito do foro íntimo. Sua carta imaginária e em tom ácido revela mais do que aversão à degradação social que denuncia desnuda suas frustrações acumuladas ao longo da vida:

No esboço inconcluso da carta, o desnudamento completo da enormidade de sua solidão explica a rigidez de um discurso moralista, vazado em inveja e amargura. Os sentimentos de aguda carência que se evidenciam realçam o descompasso entre sua escassez afetiva e íntima e o "excesso" geral: na dicotomia secura/umidade, o desvendamento de uma vida desperdiçada (Pedra, 2010, p. 2).

Severa com seu próprio discurso da carta, Maria Emília corta parte do que necessita falar, com a intensidade que lhe apetece, para que não soe vulgar nem rancorosa - ambígua e, ao mesmo tempo visceral: duas características da narrativa lygiana (Ferreira, 2014). Essa ambiguidade chega ao ponto de, estando certa vez em uma palestra feminista e desdenhando intimamente da forma como as mulheres envolvidas ali se pronunciavam sobre a anatomia feminina, em especial sobre o clitóris, ter sido ela a pessoa que mais entusiasticamente ovacionou a palestra ao final. Ou seja: até que ponto ia a sua censura? Até que ponto gostaria de ser tão liberal como aquelas mulheres que ali discutiam um tema que, à época, causava bastante mais polêmica do que hoje?

Ela aprendera com a mãe a não gostar de sexo e a ter reserva com os homens. Não é propriamente que não quisesse ter tido uma vida sexual: nunca a experimentara e nem tinha coragem de iniciá-la na velhice. No entanto, percebemos que o erótico a atrai na mesma proporção que ela o rejeita, o que denota a repressão sexual na qual foi criada e da qual não consegue fugir e que se revela, por exemplo, na alusão constante à seca no Nordeste e à cheia na Amazônia, que ela lera nas manchetes dos jornais onde a história começa. Esse binômio secura versus umidade representa sua atual esterilidade de velha, em oposição direta ao viço que tivera na juventude, além de ser uma metáfora à própria velhice em si, que a sufoca em aridez. Para Ferreira (2014), a secura da protagonista contrasta com os corpos molhados nas revistas e que lhe incitaram a ideia de escrever a carta, mas, principalmente com a famigerada e, à época, reprovadíssima cena de amor entre Marlon Brando e Maria Schneider nos papéis de Paul e Jeannie em Último tango em Paris (1972), que, para praticarem sexo anal, utilizam manteiga como lubrificante.

Essa ideia de escassez e excesso também está presente quando Maria Emília se compara às amigas que tiveram e têm afeto em suas vidas, que construíram famílias e podem contar com o apoio dos seus. Maria Emília está sozinha, somente conheceu a sobriedade dos tratamentos superficiais, não deixa frutos para a posteridade; é uma velha árvore retorcida pelos anos e cujos galhos balançam sem vigor. Apenas se mencionam seus sobrinhos, como se já não tivesse mais pais, irmãos, tios nem primos. Contudo, o papel de "tia" não lhe agrada, soa-lhe como "solteirona", como "fracassada no amor", e ela prescinde de suas presenças em seu aniversário mentindo ao dizer-lhes que não poderá estar com eles porque fora convidada para um chá pelas amigas. Na solidão do cinema, onde decide passar aquela tarde de seu natalício, sua sensibilidade se aguça para as carícias que testemunha nas poltronas que a cercam. Tudo evoca 
o sexo. Ninguém se importa com sua presença. Maria Emília é sexualmente invisível naquele contexto erótico porque é uma velha, uma velha virgem ressentida e amargurada.

Ela se percebe sozinha, mas, mesmo assim, mantém o corpo eternamente vigiado para não ceder às tentações: "[...] uma preocupação da mesma em cair em contradição com o próprio discurso empreendido. E para não "falhar" é preciso fazer algo e a única forma que tem para fugir de tanto assédio é lutar contra" (Farias, 2007, p. 3). Nota-se que seu discurso é impregnado pela experiência sexual que nunca vivenciou, pela libido que lhe fora rechaçada e que ela desviou para o trabalho. Além disso, percebemos também que a personagem deixa escapar seus desejos reprimidos em forma de atos falhos constantes, vertendo a realidade ao seu redor sempre para o contexto sexual (Ferreira, 2014).

O gosto amargo de sentir que chegara à velhice sem ter vivido sua juventude com a liberdade que os jovens necessitam e buscam repercute na personagem em forma de impotência, inveja, passividade, exasperação, medo e despeito. A vivência da liberdade sexual, que ensaiava seus primeiros passos ainda sob uma ditadura como a nossa, desperta a personagem para a certeza de sua velhice triste e vazia e para sua morte, que não seria pranteada (Pedra, 2010). Inclusive a carta, que tão urgentemente quer escrever e enviar ao diretor do jornal, queda inconclusa, apenas com o destinatário "Sr. Diretor" e nada mais além disso do que reticências. As ideias, borbulhantes e entremeadas com suas angústias e carências represadas, escaparam-lhe em torrente, mas foram mal aproveitadas, tal como sua vida, que lhe escapou sem que ela dela desfrutasse a contento.

Em resumidas palavras, podemos afirmar que Maria Emília não seria a vilã da nossa história, mas a vítima da sacralidade exigida por uma sociedade machista e autoritária que disciplina o indivíduo de forma que o mesmo se torne refém de um sistema. Maria Emília é a refém da história - sua vontade de viver plenamente sua sexualidade foi condicionada a um padrão patriarcal; o corpo não lhe pertence mais, "o corpo está preso no interior de poderes muito apertados, que lhe impõe limitações e proibições ou obrigações" (Foucault, 2007, p. 18). Assim, o corpo disciplinado de Maria Emília se opõe ao feminismo e aos ideais de sua época. Descobrir o corpo, para a personagem, é um fato pensado, mas não executado: deve ser vigiado frequentemente, pois o mesmo encontra-se dominado por estruturas muito fortes, as instituições Família, Igreja e Estado, que podemos representar pela figura do senhor diretor. Com isso observa-se que o corpo disciplinado de Maria Emília repete as regras do patriarcado, assim como a visão da família tradicional como uma instituição que deve ser mantida (Farias, 2007).

Por mais que a percepção da velhice venha sendo positivamente modificada, ela ainda é sinônimo de preconceito. Os contos analisados nesse artigo estão inseridos no contexto dos anos 1970, quando ao velho, especialmente à velha, quase sempre era reservado o silêncio de seus desejos e demandas (Zimerman, 2000). Analisando o conto lygiano, percebemos o sofrimento e a aridez de uma mulher que se sente inadequada, não pertencente socialmente e não desejada sexualmente. Marcada pelo estigma de não ter se casado, de ser uma velha virgem, Maria Emília vê-se chegar aos sessenta e dois anos de idade com um forte sentimento de incompletude e solidão.

A personagem representa a repressão sexual, a passividade e o falso moralismo a que foram submetidas as mulheres ocidentais, mais precisamente do século XVIII até o século XX. Foucault (1999) aponta o quanto a supressão da sexualidade estéril e fora do ambiente familiar provoca a repressão manifestada na exacerbação do discurso sobre a mesma, pautado de amargura, inveja e desejo, provocando o surgimento de sintomas conversivos onde o conflito inconsciente, de natureza sexual, é expresso através da linguagem corporal. Ainda segundo Foucault (1999), para suportar a inexistência da vida sexual, o sujeito passa a repulsar tudo o que possa lembrá-lo de que o seu desejo, ainda que latente, não está morto. Contudo, para a sociedade da época em que o conto foi escrito e publicado, de modo geral, era inaceitável a vivência sexual feminina na velhice. Para Freud (1917/1987), a libido negada reflete-se na neurose de conversão, como expõe Ferreira (2014, p. 62): “O discurso da protagonista nega sua sexualidade, mas seu corpo deseja e seus pensamentos estão constantemente ocupados com 'assuntos de sexo', demonstrando que sua sexualidade está viva e que tudo a faz aflorar". 
A protagonista estava imersa em um contexto dominante de sacralização das práticas sexuais, onde havia uma disciplina imposta pela Igreja, pelo Estado e pela Família para que o sexo vigiado pudesse ser feito apenas para fins de reprodução e em relações socialmente legalizadas no casamento e punido caso sua vivência fosse estéril para fins de obtenção do prazer. A docilidade a que os sujeitos, em especial as mulheres, eram submetidos negava-lhes o direito à vivência das demandas subjetivas e garantia a manutenção de uma utilidade social de preservação da moral a partir de práticas disciplinares construtoras de "subjetividade" e de uma política de coerção, adestramento e manipulação de multidões. Conforme Foucault (2007), tal disciplinarização fabricava os corpos dóceis (submissos e utilitários para manutenção da moral vigente).

Outro aspecto relevante no conto é que ao chegar à velhice, Maria Emília ainda precise afirmar-se socialmente pelo fato de não ter contraído matrimônio nem gerado filhos. Ter a sensação de não haver desfrutado da vida nem de haver tido liberdade de expressão geram sentimentos impactantes de impotência, baixa autoestima, rancor e inveja. A solidão é um dos grandes fatores de risco na velhice, que pode intensificar os efeitos deletérios de doenças crônico-degenerativas e mesmo disparar a depressão e o suicídio. À luz de Irigaray e Schneider (2007, p. 20), “a pobreza, a viuvez, a institucionalização e a solidão são identificadas também como fatores de risco para o desenvolvimento de sintomatologia depressiva. [...] frequentemente ocasionam a diminuição da autoestima, do ritmo das atividades e do interesse pelo dia-a-dia".

\section{Sobre Maria Rita em "A partida do trem"}

"A partida do trem", um dos contos que perfazem a obra Onde estivestes de noite, publicado por Clarice Lispector em 1974, relata a história de Maria Rita e Ângela Pralini, duas desconhecidas que compartilham, em uma mesma viagem de trem, o sonho de dar um novo sentido às suas vidas (Prazeres e Miglievich-Ribeiro, 2017). Apesar desse conto apresentar duas protagonistas, deter-nos-emos na análise da mais idosa delas.

Dona Maria Rita Alvarenga Chagas Souza Melo, de setenta e sete anos, cansada de morar "de favor" na casa da filha distante, public relations de uma grande empresa, decide morar na fazenda do filho Nandinho, bonachão, mas carinhoso, amparada por ele e pela família que ele formou. Sabe que terá muitos anos pela frente, porque vem de uma família longeva, e quer vivê-los rodeada pelo carinho de um lar acolhedor. Esse novo rumo em sua vida significa também, de acordo com Souza (2013), o retorno para o começo com vistas a que possa ter um fim condigno. É interessante notarmos que a filha de Maria Rita não é nomeada em nenhum momento no conto, somente o filho Nandinho. O que sabemos de sua filha é apenas o fato de que ela é uma public relations. Além disso,

A public relations, em que pese o fato de ser uma mulher, teria ultrapassado esta condição ao preço da perda da afetividade e representa o espaço público, produtivo, ou seja, o inverso da condição apresentada por Dona Maria Rita, já degradada pelo tempo e condicionada ao espaço privado que representa o lar. Portanto, não há tempo/espaço no mundo a que a filha pertence para o cuidado com a mãe idosa, abandonando-a (Prazeres e Miglievich-Ribeiro, 2017, p. 185-186).

É assim que em uma manhã, às seis horas, Maria Rita chega à Estação Central com a filha no Opala desta - símbolo de ostentação que o cargo de public relations lhe exige. Recebe um beijo frio no rosto, é colocada dentro do trem e não tem tempo de despedir-se como gostaria porque a filha parte antes, com o trem ainda parado na gare: "Recebeu o beijo gelado de sua filha que foi embora antes do trem partir" (Lispector, 1974, p. 24).

Apesar do nome pomposo, de estar bem-vestida e das joias que a cobrem, Maria Rita está desconfortável naquele ambiente: viaja sozinha - não porque seja independente, mas porque não tem companhia, é uma triste e solitária viúva. Sua ida para a casa do filho significa, em outra instância, um novo aprisionamento, ainda que mais leve. Apesar de saber que Nandinho e sua família lhe dispensarão mais carinho do que a filha, a família e os criados desta, a idosa se 
enxerga como uma indigente, "um embrulho que se entrega de mão em mão" (Lispector, 1974, p. 24), tentando parecer à vontade entre as pessoas simples que com ela viajam no trem:

Dona Maria Rita olhou de novo para o próprio anel de brilhantes e pérola no seu dedo, alisou o camafeu de ouro: "Sou velha mas sou rica, mais rica que todos aqui no vagão. Sou rica, sou rica". Espiou o relógio, mais para ver a grossa placa de ouro do que para ver as horas. "Sou muito rica, não sou uma velha qualquer". Mas sabia, ah, bem sabia que era uma velhinha qualquer, uma velhinha assustada pelas menores coisas" (Lispector, 1974, p. 24).

Seu estereótipo, mesmo ilustre, não lhe confere a respeitabilidade que ela gostaria de ter. É apenas uma velhinha entre tantas outras. Sua invisibilidade é tratada por Prazeres (2015) nestes termos: "não eram somente a solidão e a vergonha social do desamparo que a afligiam: as pessoas não a enxergavam, ela parecia não participar do tempo presente" (Prazeres, 2015, p. 98). Para Souza:

[...] a personagem Dona Maria Rita não representa uma heroína idealizada, modelo a ser seguido, ou a representação de um ideal, e sim, a simbolização do ser idoso, envolto em fracassos, agruras e crise existencial, gerados pelo estado de abandono e afastamento social (Souza, 2013, p. 82).

Sentada em frente a ela está uma jovem mulher de trinta e sete anos, Ângela Pralini. A moça mostra-se gentil com Maria Rita, assim como um jovem mais adiante na história, que faz uma delicadeza à idosa - comportamentos que a deixam desconcertada, uma vez que está desacostumada com atenções dirigidas a ela. Depois de rápidas palavras corteses trocadas entre as duas mulheres, cada uma se volta para os seus próprios pensamentos e a interação entre ambas é cortada, não voltando as duas a se falar até que Maria Rita adormece levemente e, quando acorda, já não vê mais diante de si Ângela, que havia descido em uma estação anterior (Prazeres, 2015): mais uma constatação de sua perseguidora solidão.

Ângela, tal como Maria Rita, estava indo para a fazenda de familiares para ser cuidada em um momento ingrato de sua vida. Os tios, que não tiveram filhos, mas que a tinham como filha, haviam-lhe feito o convite de a acolherem enquanto sua dor passasse: Ângela estava fugindo de um relacionamento abusivo, em que seu parceiro, Eduardo, a fazia sentir-se inferior e inadequada. Na tentativa de se encaixar e de se sentir pertencente a essa relação, havia emagrecido sete quilos. Contudo, estava insatisfeita de viver insatisfeita e deixou para trás o que com ele construíra, partindo para um momento de recuperação de forças junto aos seus. Levava apenas uma valise consigo e a esperança de que sua vida se reiniciaria a partir dali.

Ângela amava Eduardo, é certo, mas amava mais a si mesma. Era uma mulher bonita e sabia disso, era consciente de seu poder de sedução e do viço da juventude que a contemplavam: "[...] tinha os seios muito bonitos, eram seu ponto forte. Tinha as orelhas em ponta e uma boca bonita e arredondada, beijável" (Lispector, 1974, p. 27). Sabia que o tempo varreria suas dores e trariam o grande amor da sua vida para perto de si quando estivesse pronta para viver uma nova história com um novo alguém.

A juventude de Ângela contrasta com a velhice de Maria Rita. Ângela está esperançosa de refazer sua vida; Maria Rita somente almeja morrer entre os seus dali a muitos anos, amparada pelo filho que a quer com ele. Em outras palavras e segundo Figueiredo (2011), Maria Rita enxerga o futuro como uma linha reta, sem expectativas, mas amaciado pelo consolo de morrer nos braços do filho que a aceita e a acolhe. Essa ausência de Eros e a abundância de Tânatos é marcada no texto até mesmo pela posição que Maria Rita ocupa no espaço interno do trem: de frente para Ângela, mas de costas para o caminho e sem se importar com isso. Para além desse detalhe importante, ela volta para o campo, para a fazenda, que representa o interior de si mesma metaforicamente falando, e que ela quer suprir de amor (Souza, 2013). Ângela também, mas seria por pouco tempo, por seis meses apenas. Impotente frente ao futuro que a aguarda, Maria Rita se cala, não consegue exteriorizar sua subjetividade:

Acho, se disse devagarinho a velha, acho que essa moça bonita não se interessa em conversar comigo. Não sei por que, mas ninguém conversa mais comigo. E mesmo quando estou junto das pessoas, elas parecem não lembrar de mim. Afinal, não tenho 
culpa de ser velha. Mas não faz mal, eu me faço companhia. E mesmo tenho o Nandinho, meu filho querido que me adora (Lispector, 1974, p. 26).

Quer falando pouco quer silenciando, quer por meio de seu físico quer por meio de seu intelecto já tocado pela senilidade, ela expõe "o feio da condição humana, o ser imerso em insegurança e recalques" (Souza, 2013, p. 98). Carregando consigo, no final de sua longa vida, a insegurança e a frustração, Maria Rita não tem assertividade suficiente para impor-se; prefere entregar-se no presente a um futuro carregado de passado, mas também de amparo por parte de seu filho e da família que ele formou, na fazenda, longe da filha ingrata e omissa e da família e criados que a cercavam na cidade (Figueiredo, 2011):

Dona Maria Rita era tão antiga que na casa da filha estavam habituados a ela como a um móvel velho. Ela não era novidade para ninguém. Mas nunca lhe passara pela cabeça que era uma solitária. Só que não tinha nada para fazer. Era um lazer forçado que em certos momentos se tornava lancinante: nada tinha a fazer no mundo. Senão viver como um gato, como um cachorro. Seu ideal era ser dama de companhia de alguma senhora, mas isso nem se usava mais e mesmo ninguém acreditaria nos seus fortes setenta e sete anos, pensariam que era uma fraca. Não fazia nada, fazia só isso: ser velha. Às vezes ficava deprimida: achava que não servia a nada, não servia sequer a Deus (Lispector, 1974, p. 26).

“Ela se submete passivamente à realidade [...] e seu destino já está traçado e revestido de luto, pois age mecanicamente e sua trajetória está concluída e consubstanciada em premissas já fixadas", explica-nos Rabelo (2009, p. 250-251), que segue dizendo que:

[...] ela se sente como um elefante velho que é abandonado pelo grupo para morrer, pois já não consegue acompanhá-lo. Seu cenário desprovido de transcendência é alicerçado por significações já existentes que acentuam a fala inautêntica da velha senhora. [...] Sua atitude passiva se revela no carinho do filho, na indiferença da filha denominada de "public relations", [...] se situa no passado e não há indícios de poder instaurar a fala autêntica. Pelo contrário, sua conduta remonta a um ser totalmente isolado, sem sincronia com outros seres ou consigo mesmo (Rabelo, 2009, p. 252).

Lispector trata a velhice sem tapumes nesse conto (como em todos os outros onde a velhice está presente) ao ponto de usar a palavra "velha" cinquenta e duas vezes ao longo do texto, dispensando eufemismos e exagerando nas imagens dissonantes para demonstrar as agruras provocadas pela velhice em uma mulher que havia sido jovem, bela e poderosa e hoje encontrase à mercê da vontade alheia - solitária e isolada (Souza, 2013).

Em suma, à luz de Souza (2013), as duas personagens desse conto contrastam em quase tudo, especialmente na idade, que as faz enxergarem o presente e o futuro por prismas distintos e as leva a tomarem atitudes diferentes em relação à esperança. Apenas um ponto as une: ambas querem sair da situação na qual se encontram e, para isso, contam com o apoio familiar; então "apostam" na "partida do trem", do trem que as levará para longe, para a concretização desse futuro que as afaste do passado ainda no presente. Ângela, a que mais tem pulsão de vida, diz de si para consigo em determinado momento do conto: "Estou fugindo do meu suicídio, Eduardo. Desculpe, mas não quero morrer. Quero ser fresca e rara como uma romã" (Lispector, 1974, p. 27).

O narrador, onisciente, ora em primeira ou terceira pessoa ora utilizando o fluxo de consciência das personagens, nos faz enxergar o que sentem essas duas mulheres completamente estranhas uma à outra, com um lapso de quarenta anos entre elas, passageiras em uma viagem que mudará completamente o curso de suas histórias de vidas, ambas silenciadas pela violência que as cerca por não poderem se expressar livremente em seus ambientes porque seus discursos lhes são negados (Prazeres e Miglievich-Ribeiro, 2017).

O conto clariceano apresenta o despertar da consciência da velhice como uma vivência dolorosa de solidão, impotência e invisibilidade. A protagonista, Maria Rita, busca encontrar uma nova razão de viver (Frankl, 2015). Morando com uma filha que não lhe faz companhia, sente falta de ter seu valor reconhecido e de ser acolhida. Por esses motivos decide morar com o filho e a família que ele constituiu. Sente-se desamparada, não pertencente, invisível e em busca de atenção, ainda que se aprisione para consegui-la. 
O isolamento social do idoso o vulnerabiliza à solidão, à depressão, à perda do sentido de viver e à inabilidade de convivência sociofamiliar. O ser humano é um ser gregário por natureza e demandante de estar inserido no contexto relacional e dialógico para que não se perca a si mesmo, mas ultrapasse seu próprio Eu no contato com o Outro e, assim, atualize novas possibilidades, conforme Buber (1979). Para esse teórico, a realização existencial do sujeito está intrínseca no "entre", no contato interpessoal. Mesmo convivendo com a filha, a protagonista vivia imersa em completa solidão pois a relação dialógica supõe reciprocidade, um falar ao Outro, mais do que falar com o Outro; supõe a relação plena e mútua do eu-tu.

Quando Maria Rita tem uma breve interação com Ângela Pralini, naquele instante é dada à idosa uma importância a que ela estava completamente desacostumada na sua vivência familiar. Para Amatuzzi (1989), o ouvir autêntico, que difere do simples escutar, é um ato de doação amorosa, de tornar-se presente, de real interesse pelo Outro, de acolhida e encontro verdadeiro com ele e de enriquecimento pessoal. Embora muito distintas, Ângela assume um papel importante para Maria Rita ao deixar patente uma atualização de que, mesmo Maria Rita não possuindo mais a beleza, a juventude e o poder de outrora e apesar do somatório de vivências pretéritas marcadas por lutos reais e simbólicos - segundo Freud (1917/1987), processos de reações e adequações às perdas -, ainda era possível ter esperança de, no suporte familiar acolhedor, reescrever uma nova história pessoal e de sentido de vida.

\section{Considerações finais}

A velhice traz consigo uma forma distinta de perceber a passagem do tempo, que pode estar muito focada no passado ou apreensiva com o futuro. Com mais horas livres, como sói acontecer com os idosos, é fundamental que o sujeito se mantenha ocupado para não sucumbir à angústia e ao ócio. De acordo com Beauvoir (1990, p. 603): “A maior sorte do velho, mais que gozar de uma boa saúde, é sentir que, para ele, o mundo está ainda povoado de fins. Ativo, útil, escapa ao tédio e à decadência". Sair da passividade, da desvalia e do sentimento de inutilidade autoimpostos exige um esforço pessoal considerável contra crenças distorcidas, sóciohistoricamente construídas.

Maria Emília é um clássico caso da velha amargurada pela lacuna que um marido e filhos the proporcionaram, um corpo dócil foucaultiano que Telles registra magistralmente no conto "Senhor Diretor". Diferentemente dessa mulher conformada com sua inconformação, temos na Maria Rita de Lispector a quebra de grilhões, o libertar-se da filha opressora e a busca pelo filho acolhedor (ainda que pareça algo simples se comparado com os sonhos de sua companheira de viagem, Ângela, mesmo assim, em seu contexto, também realiza um ato grandioso de tomada de sentido de vida).

Maria Emília e Maria Rita, duas marias como tantas outras em nosso entorno; duas velhas tocadas pela desilusão e pela desesperança, pelo velhismo e pela dor da longevidade. Entronadas no Brasil dos anos 1970, um país endurecido pela ditadura militar e não muito permeável à efervescência feminista que varria grande parte do Ocidente de então, essas duas velhas não distam muito de nossas velhas hodiernas. Os incômodos e as questões que envolvem a velhice para as mulheres seguem sendo os mesmos, mas disfarçados sob outros aspectos - amainados em uns, exacerbados em outros.

Estudar a velhice feminina pontualmente na história e apreciar sua representação em obras legadas por autoras como Lygia Fagundes Telles e Clarice Lispector é uma satisfação e um desafio que atrai o interesse de estudiosos da Literatura e de áreas afins.

\section{Referências}

AMATUZZI, Mauro Martins (1989). O resgate da fala autêntica: filosofia da psicoterapia e da educação. São Paulo: Papirus. 
BEAUVOIR, Simone de (1990). A velhice. 4 ed. Rio de Janeiro: Nova Fronteira.

BUBER, Martin (1979). Eu e tu. Introdução e tradução de Newton Aquilles Von Zubben. 2 ed. São Paulo: Cortez e Moraes.

FARIAS, Rafaela Felex Diniz Gomes Monteiro de (2007). A disciplina do corpo feminino em "Senhor Diretor", de Lígia Fagundes Teles. Revista Fórum Identidades, Itabaiana, v. 2, n. 2, p. 1-7, jul./ dez.

FERREIRA, Josye Gonçalves (2014). Velhice desejante: sexualidade e envelhecimento na ficção de Lygia Fagundes Telles. Dissertação (Mestrado em Letras) - Universidade Estadual de Montes Claros, Montes Claros/MG.

FIGUEIREDO, Adriana Giarola Ferraz (2011). A problemática da mulher de terceira idade em contos de Clarice Lispector: uma leitura de "A partida do trem". Anais do SILEL, v. 2, n. 2. Uberlândia: EDUFU, p. 1-6.

FOUCAULT, Michel (1999). História da sexualidade humana 1: A vontade de saber. Tradução de Maria Thereza da Costa Albuquerque e J. A. Guilhon Albuquerque. 13 ed. Rio de Janeiro: Graal.

FOUCAULT, Michel (2007). Vigiar e punir: nascimento da prisão. Tradução de Raquel Ramalhete. 34 ed. Rio de Janeiro: Vozes.

FRANKL, Viktor Emil (2015). Em busca de sentido: um psicólogo no campo de concentração. 25 ed. São Paulo: Vozes.

FREUD, Sigmund (1987). Luto e melancolia [1917]. In: FREUD, Sigmund. Edição standard brasileira das obras psicológicas completas de Sigmund Freud. Rio de Janeiro: Imago. v. XIV.

IRIGARAY, Tatiana Quarti; SCHNEIDER, Rodolfo Herberto (2007). Prevalência de depressão em idosas participantes. Revista de Psiquiatria do Rio Grande do Sul, Porto Alegre, v. 29, n. 1, p. 19-27, jan./abr.

LISPECTOR, Clarice (1974). Onde estivestes de noite. Rio de Janeiro: Francisco Alves.

PEDRA, Mabel Knust (2010). Sombra silenciosa: impotência e solidão em dois contos de Lygia Fagundes Telles. Darantina Revista Eletrônica, Juiz de Fora, v. 1, n. 1, p. 1-15.

PRAZERES, Lílian Lima Gonçalves dos (2015). Femininos, identidades e trânsitos em narrativas de Clarice Lispector. Dissertação (Mestrado em Letras) - Centro de Ciências Humanas e Naturais, Universidade Federal do Espírito Santo, Vitória/ES.

PRAZERES, Lílian Lima Gonçalves dos; MIGLIEVICH-RIBEIRO, Adelia (2017). Processos de libertação (descolonização) no conto "Partida do trem", de Clarice Lispector. Antares - Letras e Humanidades, Caxias do Sul, v. 9, n. 8, p. 172-194.

RABELO, Sebastião Augusto (2009). O narrador: do tradicional ao moderno. Revista Eletrônica Via Litterae, Anápolis, v. 1, n. 1, p. 240-255.

SOUZA, Rinaldo Pereira de (2013). O ser da mulher idosa na literatura: entre o sagrado e o profano. Dissertação (Mestrado em Letras) - Pontifícia Universidade Católica de Goiás, Goiânia.

TELLES, Lygia Fagundes (1997). Seminário dos ratos. São Paulo: Companhia das Letras.

ZIMERMAN, Guite (2000). Velhice: aspectos biopsicossociais. Porto Alegre: Artmed. 